\title{
Operatīvā eksperimenta veikšanas nosacijuma izpildes problemātika
}

\author{
Mg. iur. Märcis Grinciuns \\ Rìgas Stradiṇa universitāte, Juridiskā fakultāte, Latvija \\ marcis_g@outlook.com
}

\section{Kopsavilkums}

Operatīvās darbības likuma (turpmāk - ODL) 15. panta trešajā daḷā noteikts operatīvā eksperimenta veids, kura mērḳis ir fiksēt, kā noziedzīgu vai citādi prettiesisku rīcību izraisošā situācijā rīkojas personas, attiecībā uz kurām tiek veikta operatīvā izstrāde. Rakstā tiek analizēts, kā ODL, tajā skaitā ODL 15. panta trešajā daḷā ietvertie operatīvā eksperimenta veikšanas nosacījumi, apgrūtina pasākuma realizēšanas iespējas atsevišḳu noziedzīgu nodarījumu izmeklēšanā.

Atslēgvārdi: operatīvā darbība, operatīvais eksperiments, kontrolpirkums, provokācija, kūdīšana, konkrēta persona, identificēta persona.

\section{levads}

Diskusijās ar darbiniekiem, kam uzkrāta praktiskā darba pieredze, tika secināts, ka atsevišḳu noziegumu veidu atklāšanā operatīvais eksperiments nav piemērojams, jo pastāv tiesiskā regulējuma šḳēršlıi. ODL un iestāžu iekšējās instrukcijās noteiktie pasākuma izmantošanas nosacījumi ierobežo tā izpildi pret personām, kuru identifikācijas dati nav zināmi, respektīvi, nav zināms personas vārds, uzvārds un personas kods.

Pētot Eiropola sagatavoto ikgadējo Eiropas Savienības smago noziegumu un organizētās noziedzības draudu novērtējuma (SOCTA 2017) un Interneta organizētās noziedzības draudu novērtējuma (IOCTA 2017) saturu, tika konstatēts, ka mūsdienās noziedzības apkarošanā tiesībsargājošo iestāžu lielākie izaicinājumi ir starptautiskie noziegumi, terorisms un kibernoziegumi. Tieši šo noziegumu atklāšanā personas identifikācijas datu iegūšana un tās identificēšana ODL normu un iestāžu iekšējo instrukciju regulējuma izpratnē ir īpaši sarežgīta vai bieži vien pat neiespējama, jo interneta vide noziedzniekiem sniedz plašas iespējas izmantot dažādas identitātes slēpšanas metodes, noziedznieki var izmantot viltotus dokumentus, savukārt bēgliem no terorisma riska valstīm personas 
identifikācijas dokumentu var nebūt. Tāpat nedrīkst ignorēt faktu, ka Latvijas tiesībsargājošo iestāžu darbiniekiem aizvien biežāk jāizmeklē interneta vidē pastrādāti noziegumi, kurus atklāt un pierādìt ir sevišşi grūti.

N̦emot vērā noziedzības un tehnolog̣iju attīstības tendences, l̦oti svarīgi ir attiecīgo tiesisko normu regulējumu laikus novērtēt un pilnveidot, lai tas atbilstu kriminogēnajai situācijai. Rakstā ir apskatīti vairāki prakses piemēri, kuri spilgti norāda uz personas identifikācijas datu noskaidrošanas sarežg̀itīibu, izmeklējot atsevišķa veida noziegumus, analizētas ODL normas, lai padzilịnāti noskaidrotu pētìto ODL normu vēstījumu, un aplūkota jēdzienu "konkrēta persona", "identificēta persona" un "identificēěana" nozīme no kriminālistikas un operatīvās darbības teorijas viedokḷa. Apvienojot praktiskā darba, kriminālistikas atziṇu un tiesiskā regulējuma izpētes rezultātus, ir sniegts situācijas vērtējums un priekšlikumi problēmas risināšanai.

\section{Darba mērķis, materiāls un metodes}

Šì pētijuma mērḳis - konstatēt un definēt juridisko problēmu, seviški tās praktisko aspektu, kas atseviškāās situācijās liedz efektīvi izmantot operatīvā eksperimenta pasākumu. Rakstā analizētas praktiskā darba situācijas, kurās redzama ODL normās ietverto nosacījumu negatīvā ietekme uz pasākuma izmantošanas iespējām. Pētỉjumā tiek noskaidrots, vai problēmu var risināt, grozot vai papildinot ODL vai iestāžu iekšējo instrukciju normas.

Pētỉjumā tika lietota valodnieciskā (tekstuāli gramatiskā), logiiskā, sistēmiskā un teleologiskā tiesību normu interpretācijas (tulkošanas) metode. Rezultātā tika gūta skaidra izpratne par operatīvo eksperimentu regulējošo tiesību normu vēstījuma nozīmi. Indukcijas un dedukcijas metode tika lietota, lai analīzes rezultātā iegūtā informācija un konstatējumi dotu jaunas domas (secinājumus), kas l̦autu sniegt priekšlikumus konstatēto problēmu risināšanai.

\section{Operatīvā eksperimenta nosacijumu analīze}

Jebkura operatīvā pasākuma veikšana ir piel̦aujama tikai gadījumā, ja tiek izpildīti visi ODL normās noteiktie pasākuma veikšanas nosacījumi un tā istenošana tiek pamatota ar noteikta rakstura informācijas saturu jeb pamatojumu. ODL 15. pantā ir noteikti vairāki operatīvā eksperimenta veidi, kurus pēc nepieciešamā pamatojuma un veikšanas nosacỉjumu rakstura var iedalìt divās grupās. ODL 15. panta trešajā daḷā noteiktais eksperimenta veids veicams, balstoties uz ipaša pamatojuma saturu un nosacijumu izpildi, savukārt atlikušie eksperimenta veidi istenojami, balstoties uz vispārējiem pamatojumiem un nosacijumiem.

Operatīvā eksperimenta veidi, balstoties uz vispārēju pamatojumu un nosacỉjumiem (ODL 15. panta pirmā un otrā daḷa), tiek lietoti gadījumos, ja:

- operatīvās darbības mērḳu un uzdevumu izpilde ar citiem līdzeklịem un metodēm nav iespējama vai ir būtiski apgrūtināta (ODL 4. panta ceturtā daḷa); 
- operatīvās darbības subjekta rīcībā ir informācija par noziedzīga nodarījuma izdarīšanas faktu, par kuru uzsākta operatīvā pārbaude (ODL 21. pants);

- saņemts tiešā vadītāja (priekšnieka) vai viṇa vietnieka akcepts (ODL 7. panta otrā daḷa).

Operatīvā eksperimenta veidi, balstoties uz ipaši paredzētu pamatojumu un nosacījumiem (ODL 15. panta trešā daḷa), tiek lietoti gadījumā, ja:

- operatīvās darbības mērḳu un uzdevumu izpilde ar citiem līdzekḷiem un metodēm nav iespējama vai ir būtiski apgrūtināta (ODL 4. panta ceturtā daḷa);

- uzsākts operatīvās izstrādes process (ODL 22. pants);

- operatīvās darbības subjekta rīcībā par konkrētām personām ir informācija, kura dod pietiekamu pamatu turēt šìs personas aizdomās par noziedzịga nodarījuma gatavošanu vai izdarišanu vai par valsts vai sabiedrības drošības apdraudējumu, vai arī tās tiek meklētas par izdarīto noziedzīgo nodarïjumu;

- personas ir iekḷautas operatīvajā uzskaitē (ODL 22. panta otrā daḷa un 15. panta trešã daḷa);

- saṇemts tiešã vadītāja (priekšnieka) vai viṇa vietnieka akcepts (ODL 7. panta otrā daḷa);

- saṇemts operatīvās darbības subjekta vadītāja vai viṇa vietnieka akcepts (ODL 22. panta otrā dalıa);

- sañemts prokurora akcepts (ODL 15. panta trešã dal̦a).

Redzams, ka ODL 15. panta trešās daḷas izpratnē (turpmāk, runājot par operatīvo eksperimentu ODL 15. panta trešās daḷas izpratnē, - OE) operatīvā eksperimenta veikšana paredzēta, izpildot vairākus īpašus nosacỉjumus. N̦emot vērā pētījuma mērḳus un uzdevumus, rakstā analizēts OE veids, kurš veicams, balstoties uz īpaši paredzētu pamatojumu un nosacījumu (ODL 15. panta trešã daḷa) izpildi.

Apskatot nosacījumu par operatīvās darbības subjekta rīcībā par konkrētām personām esošu informāciju, kura dod pietiekamu pamatu turēt šîs personas aizdomās par noziedzīga nodarījuma gatavošanu vai izdarīšanu vai par valsts vai sabiedrības drošìbas apdraudējumu, vai arī tās tiek meklētas par izdarìto noziedzīgo nodarījumu, var secināt, ka tas ir atvasināts no operatīvās izstrādes uzsākšanas nosacỉjuma / pamatojuma (ODL 22. pants), taču tas ir saistošs arī OE izpildē, jo šis pasākums veicams tikai pret operatīvajā izstrādē esošām personām. Saistībā ar šo secinājumu jānorāda uz būtisku apstākli - pamatojums uzsākt operatīvo izstrādi un personu iekḷaut operatīvajā izstrādē nav automātisks pamatojums veikt OE. Šāda izpratne par OE veikšanas pamatojumu nav pareiza, taču tā reizēm tiek lietota praksē - darbinieku lēmumos. Dažkārt praksē darbinieki operatīvās izstrādes uzsākšanu uztver kā formālu darbību, respektīvi, rodoties nepieciešamībai veikt $\mathrm{OE}$, amatpersona noformē nepieciešamos dokumentus operatīvās izstrādes uzsākšanai un šo pašu pamatojumu norāda OE veikšanas lēmumā, un otrādi -, uzsākot operatīvo izstrādi, amatpersona uzskata, ka ar šo brīdi tā ir tiesīga veikt jebkuru operatīvo pasākumu bez atsevišķa (papildinoša) pamatojuma. Šāda prakse nav pareiza, jo OE veikšanas pamatojumam, tāpat kā pamatojumam citiem pasākumiem, kuri aizskar 
personas tiesības, jābūt konkrētam, labi motivētam un norādītam ODL 23. ${ }^{1}$ pantā paredzētajā lēmumā.

Pasākuma veikšanas pamatojums izpaužas divējādi: pamatojumā, kādēl jālieto tieši šis konkrētais pasākums, un pamatojumā, kādēḷ pasākums jāorganizē tieši pēc ieplānotā (konkrēta) scenārija.

Plānojot OE, pamatojumā jānorāda, kādus apstākḷus pasākuma gaitā plānots radīt un kādas būs amatpersonas vai slepenā palīga darbības jeb aktivitātes. Operatīvās izstrādes uzsākšanas pamatojums ir "informācija, kas dod pietiekamu pamatu turēt konkrētas personas aizdomās par noziegumu gatavošanu vai izdarǐšanu", jeb fakti / informācija par personu noziedzīgām aktivitātēm, bet šādas informācijas saturs var arī neietvert atbildi, kādēl jāveic tieši šis amatpersonas plānotais pasākums, piemēram, OE. Lai ievērotu Eiropas Cilvēktiesību tiesas (turpmāk - ECT) noteikto pasīvas izmeklēšanas manieres kritēriju, amatpersonai OE veikšanas pamatojums un norise OE dokumentācijā jāizklāsta detalizēti, norādot, kādus apstākḷus paredzēts radìt, kāda ir paredzētā OE veicēja rīcība un kādēl tā jāpauž izvēlētajā veidā. Svarīgi norādìt informāciju, kas apliecina, ka OE ietvaros notiks iestādes "pievienošanās" plānotam noziegumam, nevis tas tiks ierosināts, kā arī jāatklāj, ka OE tiks veikts pret konkrētu personu (piemēram, "Khudobin pret Krieviju", 49., 134. rindkopa [9]). Šeit minētais ḷauj secināt, ka analizētais nosacījums, kas izriet no operatīvās izstrādes uzsākšanas pamatojuma, ir būtisks arī OE veikšanā, bet praksē, ņemot vērā pasākuma mērḳi un ECT judikatūrā noteiktos kritērijus, tas izpaužas atšķirīgi.

İpaša uzmanība jāpievērš vēl vienam OE nosacỉjumam - OE veicams pret personām, kuras ieklautas operatīvajā uzskaitē. Praksē, kā arī konsultējoties ar citiem nozares speciālistiem, nākas konstatēt, ka tieši šis nosacījums atsevišçās situācijās liedz veikt $O E$, jo dažkārt operatīvā situācija nedod iespēju noskaidrot personas identifikācijas datus. Operatīvās darbības iekšējo instrukciju regulējumā paredzēts, ka operatīvajā uzskaitē iekḷaujamās personas identifikācijas dati (personas vārds, uzvārds un personas kods) ir jāiekḷauj lēmumā par operatīvās izstrādes ierosināšanu. Tātad praksē par identificētu personu tiek uzskatīta tāda persona, kuras identifikācijas dati ir noskaidroti. Citi kritēriji, kas ḷautu veikt operatīvo izstrādi pret konkrētu personu, netiek minēti. Lìdzīgi ir ar OE plānošanu. Ja nav noskaidroti personas dati, pasākums netiks akceptēts.

Lai raksturotu problēmas izpausmi praksēe, jāmodelē trīs situācijas, kuras sastopamas tiesībsargājošo iestāžu ikdienas darbā un kuras spilgti atklāj OE tiesiskā regulējuma vai tā interpretācijas problēmu.

Pirmkārt, jāpievērš uzmanība noziegumiem, kuri izdarīti interneta vidē (kibernoziegumi) vai ar interneta vides starpniecību. Policija aizvien biežāk darba gaitā saskaras ar problēmu, ka aizliegtie priekšmeti un vielas tiek izplatitas ar interneta vides starpniecību. Piemēram, persona, kura izplata narkotikas, ar klientu par narkotisko vielu veidu, apjomu, samaksu un nodošanas kārtību vienojas sarakstes veidā, izmantojot dažādas interneta vietnes (Draugiem.lv, Facebook u. c.), elektronisko pastu (Gmail, Yahoo, Mail.ru u. c.), sazin̦as aplikācijas (WhatsApp, Viber, Signal, Telegram u. c.) un citas komunikācijas un tehnologiskās iespējas. Interneta vidē, izmantojot dažādas IP adreses slēpšanas 
metodes (piemēram, free proxy server vietnes vai, piemēram, aplikāciju Orbot, Orfox [17]), noziedznieki visai veiksmīgi var izvairīties no savas îstās IP adreses atklāšanas, pēc kuras tiesībsargājošās iestādes noziedznieku varētu identificēt. Tāpat pastāv tā sauktais melnais internets (Dark web, piemēram, Tor, Freenet), kurā personas identifikācija ir teju neiespējama [12]. Ar Tor instrumentu persona var slēpt savu identitāti un atrašanās vietu, norādot valstis, kurās persona patiesībā neatrodas [11]. Šie apstākḷi policijai rada ne tikai personas identifikācijas grūtības, bet pat nozieguma izmeklēšanas piekritības (jurisdikcijas) problēmas, jo sarežgîti ir noskaidrot, kurā valstī persona noziegumu ir izdarỉjusi.

Lai noskaidrotu identitāti personai, kura slēpjas, lietojot tehniskās un interneta vides tehnologiiskās iespējas, policijai OE ietvaros jārada noteikti apstākḷi (situācijas), kuru dēḷ persona, kas veic noziegumu, piekrīt nodibināt kontaktu ar OE veicēju. Taču, lai šādu situāciju radītu, nepieciešams $O E$ veikšanas akcepts no operatīvās darbības subjekta amatpersonas tiešā priekšnieka, iestādes vadìtāja un prokurora. Lai akceptu iegūtu, jāizpilda ODL minētie nosacījumi, respektīvi, persona, kuras vārds, uzvārds un personas kods nav zināms, jāiekḷauj operatīvajā izstrādē, bet to izdarīt nevar, jo iestādei šì informācija nav zināma un apstākḷi liedz to noskaidrot. Tādējādi tiek paralizēts tiesībsargājošo iestāžu darbs. Minētais attiecas uz jebkuru noziegumu, kurš izdarìts, pērkot un pārdodot aizliegtus priekšmetus, piemēram, ieročus vai būtiskas to sastāvdal̦as [4], bērnu pornogrāfijas materiālus.

ODL 22. panta pirmās daḷas regulējumā noteikts, ka operatīvā izstrāde uzsākama pret konkrētām personām, ja operatīvās darbības subjekta rīcībā ir informācija, kas dod pietiekamu pamatu turēt šīs personas aizdomās par noziedzịga nodarỉjuma gatavošanu vai izdarīšanu. Jēdziens "konkrēta persona" atbilstīgi apskatītās normas saturam būtu jātulko plašāk nekā personas identifikācija pēc vārda, uzvārda un personas koda. Ja jēdziens "konkrēta persona" tiek vērtēts kā nosacijums, kurā paredzēts interesējošo personu izdalìt no visas sabiedrības kā vienīgo indivīdu, kurš izdarīis konkrēto nodarījumu vai kurš atradies kādā konkrētā vietā, viṇu iespējams identificēt pēc, piemēram, pirkstu nospiedumiem, DNS, balss u. c. personas unikālajām pazīmēm. Taču jēdzienu "konkrēta persona" var interpretēt arī kā nosacījumu, kas ierobežo iestāžu veikto operatīvo darbību pret nekonkrētu personu loku. Respektīvi, ja operatīvā darbība tiek veikta pret nekonkrētām personām, tā faktiski pārkāpj iedzīvotāju tiesības uz privātās dzīves, mājokḷa un korespondences neaizskaramību, jo pasākumi tiek organizēti bez likumīga pamatojuma.

Saistībā ar iestādes rīcību pret nekonkrētu personu ECT savu viedokli paudusi lietas "Khudobin pret Krieviju" spriedumā. Lietas "Khudobin pret Krieviju" sprieduma 49. un 134. rindkopā teikts, ka iesniedzējs (Khudobin) pirms aizturēšanas (lietas ietvaros, kura izskatīta ECT) iepriekš nav sodīts. Vienīgā informācija, kas liecināja par iesniedzēja saistību ar narkotisko vielu izplatîšanu, saṇemta no viena policijas slepenā informatora (sievietes). Liecību sniegšanas laikā informatore ECT norādījusi: "Tajā laikā es nezināju, kur iegūt heroìnu, tāpēc toreiz es izlēmu zvanīt [Khudobin], jo agrāk viṇš man bija tās pārdevis." ECT konstatēja, ka iesniedzējs neguva nekādu finansiālu ieguvumu, pārdodot narkotikas informatorei, jo iesniedzējs narkotikas iegādājās no citas personas, samaksājot 
personai tikpat, cik vēlāk pārdošanas brīdī pieprasiija informatorei. No minētajiem apgalvojumiem ECT secināja, ka iesniedzējs nav policijai zināms narkotiku tirgotājs un policijas operācija netika vērsta konkrēti pret iesniedzēju, bet gan pret jebkuru personu, kas piekristu piegādāt heroīnu informatorei [9]. No sprieduma satura secināms, ka pirms minēto policijas aktivitāšu veikšanas policijai bija jāiegūst konkrēts pamatojums, kas norāda uz iesniedzēja saistību ar narkotisko vielu izplatīšanu. Ja šāds pamatojums netika iegūts, nedz nacionālā tiesa, nedz ECT nespēj noteikt, vai iestāde bija "pievienojusies" kriminālām darbībām vai tās izprovocējusi (iniciējusi).

Jebkurš plānotais operatīvais pasākums veicams ar konkrētu pamatojumu: kādēl pasākums jāveic (ko plānots sasniegt) un kādēl jāveic tieši šis konkrētais izvēlētais pasākums pēc konkrētā scenārija (piemēram, pamatojums personas cilvēka pamattiesību ierobežojumam, izpildot attiecīgu operatīvo pasākumu). Ja operatīvā darbība tiek veikta bez objektīva un konkrēta pamatojuma, tas nozīmē, ka jebkurš cilvēks var kḷūt par iestādes mērḳi un pret vinu var tikt izmantotas operatīvās darbỉbas subjekta rīcībā esošās ekskluzīvās operatīvo darbību metodes, taktika un speciālās tehnikas iespējas, taču šāda rīcība demokrātiskā sabiedrībā nav piel̦aujama. Apskatītā ECT sprieduma situācija atklāj, ka šajā gadỉjumā iestādes pamatojums bija pārāk vispārīgs ("notvert narkotiku tirgotāju"), tādēḷ pasākums tika vērtēts kā veikts pret nekonkrētu personu loku.

OE pasākuma sākšana pret personu, kura kādā interneta portālā slēpjas aiz konkrēta lietotājvārda, nav uzskatāma par pasākumu pret nekonkrētu personu, bet gan pret personu, kura konkrētajā interneta vietnē, izmantojot konkrētu lietotājvārdu, nodarbojas ar noziedzīgām aktivitātēm, t. i., veic saraksti, organizējot noziedzīga nodarïjuma izpildi. Dialogs OE ietvaros, tostarp sākotnējā sarakstē interneta portālā, OE veicējam notiks ar konkrētu personu, kura izmanto konkrētu lietotājvārdu. OE pirmajos posmos persona tiks identificēta, jo ar to tiks nodibināts jau fizisks (redzes) kontakts, un šis notikums tiks fiksēts ar audio un video fiksējošu aparatūru. Nedrīkst aizmirst, ka viens no OE mērķiem var būt informācijas pārbaude. L,aujot veikt OE pret konkrētām personām, kuras iespējams izškirt pēc lietotājvārda un to veiktās sarakstes satura internetā, iestādes var pārliecināties par iegūtās informācijas patiesumu un identificēt konkrēto personu, kā arī atbilstoši plānot turpmāko operatīvo darbību. Informācijas pārbaude OE ietvaros nenozīmē, ka persona tiek ievilināta slazdā vai provocēta uz noziedzīgu rīcību, kā, piemēram, tas izpaudās deviṇdesmito gadu sākumā Kanādas Karaliskās policijas (Royal Canadian Mounted Police, RCMP) attīstītajā slepenās operācijas tehnikā Mr. Big, kuras ietvaros policijas darbinieks, kurš uzdevās par noziedznieku ar labiem kontaktiem policijā, personai radijja priekšstatu, ka viṇa iesaistās noziedzīgās aktivitātēs (lai gan persona ar šādiem noziegumiem agrāk nebija saistīta). Metodes sākotnējais mērḳis bija iegūt personas uzticību. Pēc tās iegūšanas policijas slepenais darbinieks jeb tā sauktais $M r$. Big pazinnoja, ka viṇam esot kontakti policijā un tie var palīdzēt atbrīvoties no tikko iegūtiem pierādỉjumiem, kas, neapšaubāmi, apstiprināja personas vainu agrāk izdarītajā noziegumā (kas bija policijas sākotnējās intereses objekts un tā dẹl tika lietota šì slepenās operācijas tehnika), taču šai personai jāizstāsta, kā viņš izdarīja šo noziegumu, atklājot visas detaḷas. 
Ja persona to nedarīs, palīdzību nesaṇems [10; 16]. Šāda policijas aktivitāte neapšaubāmi ietver provokācijas un slazda pazīmes. Šāda metode Eiropas demokrātiskajā sabiedrībā nav piel̦aujama. Informācijas pārbaude OE ietvaros, bez šaubām, neparedz minētās tehnikas provokācijas un slazda izpausmes, kas personu varētu ietekmēt atzīties noziegumā, ko patiesībā tā nav izdarījusi.

Domājams, dal̦a praktiķu uzskata, ka OE veikšana tūlītēji nozīmē personas faktiskās noziedzīgās rīcības - narkotiku iegādes brīža, kukuḷa nodošanas brīža - fiksēšanu, taču praksē tā nav. Bieži vien līdz patiesajam nozieguma fiksēšanas brīdim paiet garš izzināšanas process. Tā gaitā var tikt noskaidrota gan personas motivācija, gan līdzdalïbnieki, gan pierādījumu avoti, gan cita izmeklēšanai svarīga informācija. OE plānošanas un izpildes gaitā nav piel̦aujama personas provocēšana uz noziedzīgu rīcību, kā arī jārēḳinās, ka nākotnē iestādes rīcību var vērtēt ECT, skatot jautājumu, kā iestādes (un OE veicēja) aktivitātes ietekmēja un vai ietekmēja personu izšķirties par noziedzīgu rīcību. Nav pamata bažām, ka informācijas pārbaude OE ietvaros ietekmēs pasākuma tiesiskumu. OE veikšana izzināšanas / informācijas pārbaudes nolūkos nav prettiesisks pasākums, tieši pretēji - tā rezultāti lauj iestādei efektīvāk plānot turpmāko darbu un sasniegt kompetences mērḳus un uzdevumus.

Vērtējot konkrētas personas izdalīšanu no pārējās sabiedrības pēc tās lietotājvārda kādā interneta vietnē vai pēc lietotā tālruṇa numura kritērijiem, jānoskaidro, vai šie kritēriji ir pietiekami, lai izdalītu indivīdu kā konkrētu un veiktu pret to aktivitātes. Interneta vietnes konts, neapšaubāmi, var tikt vienots ar cilvēku, kurš ar šì konta starpniecību pauž attiecīgu informācijas saturu (piemēram, sarakstē), tāpat arī tālruṇa numurs var tikt vienots ar tā lietotāju, kurš ar tā starpniecību pauž savu subjektīvo viedokli sarunās vai îszinu sarakstē.

Pēc autora domām, ja ir fiksēts sakaru līdzeklis (lietotājvārds, tālruṇa numurs u. tml.), ar kuru tiek pausta operatīvu interesi izraisoša informācija, kas norāda uz sakaru līdzekḷa lietotāja noziedzīgo aktivitāti, vai kāds priekšmets (automašīna), kurš fiksēts kā nozieguma izdarīšanas līdzeklis vai palīglīdzeklis, operatīvā darbība pret personām, kuras saistītas ar šiem sakaru līdzekḷiem vai priekšmetiem, ir piel̦aujama. Operatīvā darbība šādā gadījumā tiktu veikta tieši pret šo konkrēto personu, kura izmanto konkrētu sakaru lìdzekli vai transportlīdzekli. OE tiktu pamatots ar personas sarakstēs vai sarunās pausto informācijas saturu un avotu, kur šĩ informācija iegūta.

Otrkārt, modelējot situācijas, kuras spilgti atklāj OE tiesiskā regulējuma vai tā interpretācijas problēmu, jāpievēršas apstākḷiem, kas rodas cīṇā ar terorismu vai atklājot noziegumus, kurus veic bēgḷi no terorisma riska valstīm vai personas, kuru identitātes datus noskaidrot nav iespējams.

Latvijā un citur Eiropā tiesībsargājošās iestādes praksē saskaras ar problēmu, ka noziegumus izdara personas, kas ieradušās no terorisma riska valstīm un Eiropā ieceḷojušas bēg̣̣a statusā. Bieži šīm personām nav identifikācijas dokumentu vai tie ir viltoti. N̦emot vērā situāciju arābu valstīs, kurās notiek karadarbība un vide Eiropas iedzīvotājiem un to izvēlētajam politiskajam kursam ir nedraudzīga, personu identitātes pārbaude ir 
ierobežota vai pat neiespējama, jo šo valstu iestādes nav ieinteresētas tērēt resursus un sniegt nepieciešamo atbalstu Eiropas valsts iestādei, lai palīdzētu identificēt kādu bēgli Eiropā. Turklāt persona var atteikties nosaukt savus identitātes datus vai var nosaukt nepareizus datus, kas personas pārbaudi novedīs strupcel̦ā. Eiropas plašsaziñas līdzekḷos rodama informācija, ka viens no trīs bēgḷiem, kuri ieradušies no Sīrijas, Eiropā ieceḷojuši ar viltotiem personu apliecinošiem dokumentiem, kuros norādīts neīsts vārds, uzvārds un valstiskā piederība. Vācijas Iekšlietu ministrijas pārstāvis kādā intervijā norādīja, ka 2015. gada laikā Vācijā ieradušies aptuveni 527 tūkstoši bēgḷu, no kuriem aptuveni 30 \% bijuši viltoti dokumenti [20]. Kopš 2015. gada šādu bēgḷu skaits ir ievērojami palielinājies. Turklāt jāatceras, ka Eiropā iecel̦ojušie bēg̣̣i galvenokārt ierodas no terorisma riska valstīm, tādējādi arī potenciālie terorisma riski ievērojami pieaug.

Piemēram, iespējama situācija, ka tiek iegūta informācija par šāda indivīda (bēgḷa) interesi par ieroču vai sprāgstvielu iegādi un nepieciešams veikt attiecīgus operatīvās darbības pasākumus, lai atklātu un fiksētu personas noziedzīgus nolūkus un aktivitātes. Tajā pašā laikā personas identitātes dati nav zināmi, un, n,emot vērā augsto iespējamību, ka personas identifikācijas dokumenti varētu būt viltoti, zūd ODL 15. panta trešajā daḷā ietvertā nosacījuma jēga. Ja pēc personas dokumentiem noskaidrotais vārds un uzvārds, iespējams, tāpat nav personas īstais vārds, vai ir nozīme, kāds vārds tiek ierakstīts lēmumā par personas iekḷaušanu operatīvajā uzskaitē un lēmumā par OE veikšanu? Kā noskaidrot personas īstos datus, ja, piemēram, nav zināms, no kuras valsts persona ieceḷojusi? Savukārt, ja arī valsts ir zināma, cik ilgu laiku aizṇems tiesiskās palīdzības lūguma izpilde un vai tā vispār tiks sniegta, piemēram, lūdzot Sīrijas tiesībsargājošajām iestādēm identificēt kādu Sīrijas pilsoni? Tomēr situācija ir jārisina nekavējoties, jo policijas iesūtītā cilvēka kontakts ar interesi izraisošo personu nebūs noturīgs: ja šì persona nesaṇems prasītos ieročus, viṇa tos meklēs citur, un OE veicējam nebūs iemesla ar personu turpmāk uzturēt kontaktu. Var secināt, ka normatīvais regulējums un praksē ieviestā kārtība liedz efektīvi atklāt noziegumus, kuros iesaistītās personas izmanto viltotus dokumentus vai to identitātes datu noskaidrošana ir sevišḳi sarežg̀ita.

Treškārt, jāpakavējas pie analizētā nosacījuma izpausmes pretizlūkošanas darbā. Klasiskā izpratnē izlūkošana ir citas valsts izlūkdienesta amatpersonas vai tās rekrutētas personas aktivitāte kādas interesējošas valsts teritorijā ar nolūku iegūt izlūkošanas informāciju. Savukārt pretizlūkošana ir aktivitāte pret izlūkdienestu darbībām. Interesējošās valsts teritorijā izlūkdienesta amatpersonas darbojas leǵendēti, respektīvi, to atrašanās valsts teritorijā tiek pamatota ar dažādiem izdomātiem iemesliem, citādi viṇu darbība nebūtu efektīva. Bijušais Padomju Sociālistisko Republiku Savienības Bruṇoto spēku generālštāba Galvenās izlūkošanas pārvaldes (izlūkdienestu vidē pazistama kā GRU) darbinieks, kurš savas karjeras laikā strādājis diplomātiskajā rezidentūrā Ženēvā, grāmatā "Spiegošanas pamati" raksta:

"Aizsegam varēja izmantot praktiski jebkuru amatu jebkurā padomju iestādē ārzemēs; jebkurš padomju pilsonis, kurš izbrauca ārpus Padomju Savienības, varēja pildīt izlūkošanas uzdevumus, un lielākā daḷa šādu cilvēku patiešām veica izlūkošanas darbu. Vēstnieks 
un vēstnieka šoferis, konsuls un vēstniecības apsargs, viesizrādēs atbraukusi balerīna, rakstnieks vai mākslinieks, parasti tūristi un viṇu gidi, stjuarti, padomju delegāciju vadītāji un locekḷi, ANO darbinieki un pat mācītāji varēja izrādīties GRU virsnieki." [18, 123]

Valstĩ iesūtītie izlūkdienesta darbinieki izmantoja segdokumentus un legendu, citādi viṇu uzdevumu izpilde ārzemēs nebūtu iespējama. Specializētajā literatūrā par to rakstìts, ka segdokumenti tiek izmantoti operatīvās darbības konspirācijas nodrošināšanai, lai apliecinātu izlūkdienesta amatpersonas izvēlētos identitātes datus un / vai piederību kādai iestādei, organizācijai, uzṇēmumam vai firmai, tādējādi nodrošinot attiecīgā operatīvā (izlūkošanas) uzdevuma izpildi un noslēpjot piederību izlūkdienestam un / vai îsto identitāti [14, 261]. Valsts iekšējai drošîbai bīstamākie izlūkdienestu darbinieki ir tā sauktie nelegāḷi, kuri valstî ierodas ar īpaši dziḷi izstrādātu legendu, kas nekādā veidā neasociējas ar valsti, kuru pārstāv izlūkdienests, un izlūks (nelegālis) var nedarbosies kā valsts pārstāvis valstiskā organizācijā. Šādas personas identificēt ir īpaši sarežg̀îti, jo viṇas ir speciāli apmācītas, lai pretdarbotos pretizlūkošanas dienestu aktivitātēm, un viṇu legendas ir sevišķi labi izstrādātas. Nelegāḷi vienmēr slēpj savu identitāti un bieži vien arī piederību konkrētajai valstij. Operatīvās darbības (izlūkošanas darbības) teorijā un praksē jēdziens "nelegālis" tiek skaidrots kā persona, kas dzīvo un darbojas ar daḷēji vai pilnībā izdomātiem identitātes datiem un viltotiem dokumentiem, kā arī legendètu dzīves gājumu [14, 185].

Pretizlūkošanas darbā prakse, ka izlūks izmanto segdokumentus un atbilstīgu legendu, ir pašsaprotama, un tā atsevišḳos gadījumos var būt log̣iska izlūkdarbības izpausmes daḷa. To zinot, rodas jautājums, kā pret šādām personām iespējams veikt $\mathrm{OE}$, ja vinuu īstie personas identifikācijas dati, visticamāk, nekad nebūs zināmi. Šāda rakstura informāciju iespējams noskaidrot tikai izlūkošanas rezultātā, piemēram, rekrutējot augsta līmeṇa valstij nedraudzịgā izlūkdienesta amatpersonu, kurai ir piekḷuve ārzemēs darbojošos nelegāḷu identificējošajiem datiem. Šāds rezultāts - rekrutēta augsta līmeṇa izlūkdienesta amatpersona - ir viens no augstākajiem izlūkdienestu rezultātiem, kāds iespējams, un to realizēt diezgan reti izdodas pat spēcīgākajiem izlūkdienestiem pasaulē, respektīìi, nedrīkst paļauties uz to, ka tik tiešām izdosies noskaidrot izlūka patiesos datus.

Protams, iekḷaujot lēmumā "par personas iekḷaušanu operatīvajā uzskaitē" un lēmumā "par OE veikšanu" personas neīstos datus, formāli būs izpildìts likumā noteiktais nosacījums un OE varētu veikt, bet, ja amatpersona apzinās, ka dati personu patiesībā neidentificē, bet drīzāk apzīmē, kā vērtēt šādu amatpersonas rīcību no tiesiskā un ètiskā viedokḷa? Pēc autora domām, šis nosacìjums praktiskajā darbā var radīt un rada aplamu, pat neētisku rīcìbu.

\section{ODL regulējuma vēstijums}

Atbildes uz šeit aplūkotajiem jautājumiem, iespējams, sniegs ODL 22., 23. un 15. panta tulkošanas (interpretācijas) rezultāti, kas iegūti, lietojot sistēmiskās un teleolog̣iskās tiesību normu interpretācijas metodes. 
Mārcis Grinciuns. Operatīvā eksperimenta veikšanas nosacijuma izpildes problemātika

Vispirms nepieciešams noskaidrot, kas ODL normu izpratnē ir identificēta jeb operatīvajā uzskaitē iekḷaujama persona un kādi kritēriji jāizpilda, lai personu iekḷautu operatīvajā uzskaitē un uzsāktu tās operatīvo izstrādi. Ar sistēmiskās interpretācijas metodes palïdzību var noskaidrot tiesību normas jēgu saistībā ar citām tiesību normām [1], tādēl jautājums tiek pētìts OLD 22. un 23. panta vēstījumu kontekstā, no kuriem izriet ODL 15. panta trešās dalas nosacījums, ka "OE veicams pret personām, attiecībā uz kurām tiek veikta operatīvā izstrāde”. Savukārt ar teleoloğisko (jēgas un mērḳa) interpretācijas metodi iespējams noskaidrot tiesību normas jēgu, pamatojoties uz lietderīgu un taisnīgu mērḳi, kas jāsasniedz ar attiecīgo tiesību normu [1]. Normu jēga meklējama operatīvās darbības mērḳos, uzdevumos un konkrētā operatīvā pasākuma mērḳos.

Lai uzskatāmāk atklātu ODL 22. un 23. panta saturu, kurā skaidrots, kas ir operatīvajā uzskaitē iekḷaujama vai izstrādājama persona un kādi ir uzskaitē iekḷaujamas personas identifikācijas kritēriji, šo normu izklāsts (kur pieminēta operatīvajā uzkaitē iekḷaujama vai izstrādājama persona) sniegts tabulā (sk. 1. tab.), pēc kuras veikta to analīze un tulkošana, lietojot nosauktās juridiskās tulkošanas (interpretācijas) metodes.

1. tabula. Operatīvās darbības likuma 22. un 23. panta satura izklāsts*

\begin{tabular}{|c|c|c|}
\hline $\begin{array}{c}\text { Panta } \\
\text { daḷa }\end{array}$ & 22. pants & 23. pants \\
\hline 1. & $\begin{array}{l}\text { Ja operatīvās darbības subjekta rīcībā ir } \\
\text { informācija par konkrētām personām } \\
\text { (iegūta arī operatīvās pārbaudes rezultātā) } \\
\text { un tā dod pietiekamu pamatu turēt šīs } \\
\text { personas aizdomās par noziedzīga nodarījuma } \\
\text { gatavošanu vai izdarǐšanu [..], attiecībā uz šīm } \\
\text { personām jāuzsāk operatīvā izstrāde. }\end{array}$ & $\begin{array}{l}\text { Operatīvās darbības subjekti ir tiesīgi vākt, } \\
\text { sistematizēt, analizēt, uzglabāt un uzskaitīt } \\
\text { publiski pieejamo un slepeno informāciju } \\
\text { par personām, faktiem, notikumiem } \\
\text { un lietām (pasīvā uzskaites forma), } \\
\text { kas nepieciešama un kam ir nozīme } \\
\text { operatīvās darbības un kriminālprocesa } \\
\text { uzdevumu veikšanai. }\end{array}$ \\
\hline 2. & - & $\begin{array}{l}\text { lekḷaut personas operatīvajā uzskaitē (aktīvā } \\
\text { uzskaites forma) ir ațauts tikai tad, ja attiecībā } \\
\text { uz tām tiek veikta operatīvā izstrāde. }\end{array}$ \\
\hline 3. & $\begin{array}{l}\text { Par operatīvo izstrādi jāierosina operatīvās } \\
\text { izstrādes lieta, bet personas, attiecībā } \\
\text { uz kurām tiek veikta operatīvā izstrāde, } \\
\text { iekḷaujamas operatīvajā uzskaitē. }\end{array}$ & $\begin{array}{l}\text { Operatīvajā uzskaitē iekļauto personu tiesības } \\
\text { un brīvības var ierobežot tikai Kriminālprocesa } \\
\text { likumā vai citos likumos noteiktajos gadījumos } \\
\text { un kārtībā. }\end{array}$ \\
\hline 4. & - & $\begin{array}{l}\text { 2. punkts: Ja ziņas, uz kuru pamata } \\
\text { persona iekllauta operatīvajā uzskaitē, } \\
\text { nav apstiprinājušās, šī persona no uzskaites } \\
\text { noṇemama. Operatīvās uzskaites lietas } \\
\text { (operatīvās pārbaudes un operatīvās izstrādes } \\
\text { lietas) izbeidzamas, ja: } \\
\text { 1) [...]; } \\
\text { 2) noziedzīgs nodarījums un šo } \\
\text { noziedzīgo nodarījumu izdarījušās } \\
\text { personas ir noskaidrotas. }\end{array}$ \\
\hline
\end{tabular}

* Citēti visi fragmenti, kuros pieminēta (raksturota) uzskaitē iekḷauta vai izstrādājama persona. 
Var secināt, ka ODL nav noteikti konkrēti kritēriji, kas raksturo identificētu personu. Tajā arī nav atrodama informācija, kas detalizētāk raksturotu operatīvajā uzskaitē iekḷaujamu (identificētu) personu. Vienīgais operatīvajā uzskaitē iekḷaujamas jeb izstrādājamas personas kritērijs atrodams ODL 22. panta pirmajā daḷā - tajā noteikts, ka šīm personām jābūt "konkrētām".

Kā tas tika skaidrots iepriekš, šo nosacījumu var izprast divējādi:

1) jēdziens "konkrētām personām" tiek lietots, lai operatīvo darbu izstrādes ietvaros veiktu darbības attiecībā uz noteiktām personām (persona fiksēta kā konkrētas automašinnas vai tālruṇa numura lietotājs vai, piemēram, kādas interneta vietnes konta lietotājs) jeb nepielıautu operatīvās darbības pret nekonkrētu personu loku;

2) jēdziens "konkrētām personām" tiek lietots, lai operatīvais darbs izstrādes ietvaros tiktu veikts tikai pret konkrētiem indivīdiem, kurus iespējams izšḳirt (identificēt), un tie ir identificēti pēc to unikālajām pazīmēm (pirkstu nospiedumiem, DNS, vizuālajām īpašībām, balss u. c. indivīda unikālajām pazīmēm).

Normu interpretācijas rezultāti ḷauj secināt, ka likumā noteikts stingrs operatīvās darbības ierobežojums pret nekonkrētu personu loku, savukārt tas, ka izstrādes uzsākšanas brīdī persona nav identificēta, neierobežo operatīvo darbỉbu pret konkrētām personām, kuras no sabiedrības izšķiramas pēc citiem kritērijiem.

Vērtējot nosauktās ODL normas un ODL noteiktos principus (4. pants) no teleologiskās tulkošanas metodes viedokḷa, var secināt, ka būtiskākais operatīvās darbības mērḳis ir aizsargāt personu un sabiedrības intereses un nodrošināt tiesiskumu (operatīvās darbības veikšanu, ievērojot personu tiesības) iestāžu darbā. Ja normatìvajā regulējumā nav stingri noteikts, ka, iekḷaujot personu operatīvajā uzskaitē, obligāti jāzina tās identifikācijas dati, tad, ņemot vērā operatīvās darbības būtību un mērḳi, iestādes ir tiesīgas interpretēt un piemērot ODL normas tā, lai darbu veiktu iespējami efektīvāk (to paredz arī operatīvās darbības principi), bet, ievērojot nosacījumu, lai interpretēto normu piemērošanas dēl iestāžu darbs nekḷūtu prettiesisks.

Var secināt, ka vispārzināmie un plaši lietotie personu identifikācijas veidi - personas DNS, pirkstu nospiedumu, ārējo pazīmju jeb habitologiskās (piemēram, portreta), balss jeb fonoskopiskās, smaržas jeb odoroloǵiskās ekspertīzes - ir leǵitīmi un pasaulē atzìti identifikācijas veidi, tādẹl nav šḳēešḷ̆u, kas liegtu šos paṇēmienus izmantot arī operatīvajā darbībā. Arī apskatìto likuma normu regulējumā nav stingri noteikts, ka operatīvo darbību izstrādes ietvaros nedrīkst vērst darbības pret personām, kuras nav identificētas. Likumā noteikts, ka ḷauts operatīvo darbību vērst pret konkrētu personu vai konkrētu personu loku, kuras ir saistītas, piemēram, ar operatīvās darbỉbas gaitā fiksētu, operatīvo interesi izraisošu automašīnu (nepieciešams reǵistrācijas numurs), tālruṇa numuru vai, piemēram, Draugiem.lv konta lietotājvārdu.

Uzskatu, ka likuma regulējums ir pietiekami elastīgs, lai operatīvās darbības subjekti tā ietvaros spētu leǵitīmi sasniegt savas kompetences mērḳus un uzdevumus. 


\section{Personas (un priekšmetu) identifikācija kriminālistikas teorijas izpratnē}

Operatīvās darbības teorija Latvijā tiek pētīta un pilnveidota juridisko zinātṇu kriminālistikas un operatīivās darbības teorijas apakšnozarē [15]. Tātad abi zinātnes apakšnozares virzieni ir saistīti un viens otru papildina, un tāpēc ir svarīgi noskaidrot, ko kriminālistikas teorija vēsta par jēdzienu "identifikācija". Kriminālistikas zinātniskajā literatūrā teikts, ka nozieguma atklāšanas interesēs visai bieži ir svarīgi noteikt, vai notikuma vietā atstātās pēdas atstājusi noteikta persona; vai liecinieks redzējis tieši šo cilvēku; vai no līḳa izṇemtā lode ir izšauta no aizturētajam atṇemtā ieroča, u. tml. Visos šajos gadījumos tiek veikta minēto objektu - cilvēka vai ieroča - identifikācija. Kriminālistikas literatūrā tiek skaidrots, ka termins "identifikācija" cēlies no latīnu identificare, kas nozīmē tāpatības noteikšanu. Tam pamatā ir latīnu izcelsmes vārds idem - identisks, tas pats. Identificēt nozīmē noteikt, vai zināmais objekts - cilvēks, ierocis, apavs - ir meklējamais, tātad tas pats, kas šajā gadijumā interesē. Minētā identitātes jēdziena izpratne jāskaidro šādi: "Noskaidrot personu, kas izdarījusi noziegumu, nozīmē visu cilvēku vidū izdalìt to vienīgo indivīdu, kurš izdarījis konkrēto nodarījumu." [13, 89] No minētā var secināt, ka identificēta persona ir tāda persona, kuru pēc tās individuālajām pazīmēm iespējams atškirirt no pārējām personām sabiedrībā.

Atbilstīgi kriminālistikas teorijai un praksei personu iespējams identificēt pēc personas genētiskās informācijas koda (dezoksiribonukleīnskābes (DNS) sastāva pazīmēm) informācijas, kura katram cilvēkam ir unikāla un nav maināma, kā arī pēc pirkstu (arī pēdu) nospieduma unikālajām pazīmēm (nosaka daktiloskopiskā ekspertīzē), pēc fonoskopiskās ekspertīzes slēdzienā konstatētajām personas unikālajām balss pazīmēm un arī pēc personas ārējo pazīmju raksturojuma (nosaka habitologiskā ekspertīzē). Škiet dīvaini, taču ir tā, ka kriminālistikas teorija klusē par personas identificēšanu pēc vārda, uzvārda un personas koda. Taču šai klusēšanai ir pamatojums. Vārds, uzvārds un personas kods nav nemainīgi vienumi, un nav iespējams uz tiem balstìt zinātniskus secinājumus, kas l̦autu visos gadījumos praksē nešaubīgi atzìt, ka šì persona ir tieši meklētā un neviena cita. Personas vārdu un uzvārdu vienmēr salīdzina ar informācijas sistēmā vai policijas kartotēkā pieejamo fotogrāfiju, kurā redzama persona, kas jāidentificē. Bez personas attēla vārdam un uzvārdam personas identifikācijā ir maza nozīme.

Personu identifikāciju pēc ārējām individuālajām pazīmēm pēta kriminālistikas habitolog̣ijas nozare. Zinātniskajā literatūrā rakstīts, ka habitolog̣ija ir kriminālistikas nozare, kas pēta likumsakarības, pēc kurām veidojas informācija par cilvēka ārienes pazīmēm, un uz to izzināšanas pamata izstrādā šo pazīmju klasifikāciju, kā arī līdzekḷu, paṇēmienu un metožu sistēmu to fiksācijai un izmantošanai noziegumu atklāšanā, izmeklēšanā un meklējamo personu atrašanā $[13,93]$. Jāatzīmē, ka personu atpazīšana pēc ārējām pazīmēm tiek veikta arī kriminālprocesa ietvaros un to paredz Kriminālprocesa likuma 175. pantā noteiktā izmeklēšanas darbība "uzrādīšana atpazišanai" [5]. Minētais paṇēmiens ir legiitīms, un visā pasaulē tas tiek izmantots noziegumu pierādīšanā. Savukārt 
daktiloskopiskās metodes efektivitāti raksturo zinātnisku pētījumu secinājumi par to, ka cilvēka pirkstu galu rievoto ādas virsmu klāj papillāro līniju raksts, kura aina katram cilvēkam ir stingri individuāla, un šis raksts ir nemainīgs visas dzīves laikā, sākot no 7. attīstības mēneša mātes miesā līdz satrūdēšanai $[13,134]$. Minētās metodes ir balstìtas uz zinātnisku pētỉjumu rezultātiem, un tās noziegumu pierādī̌anā ir atzìtas par leǵitīmām visā pasaulē.

\section{Problēma operatīvās darbības būtības un mērḳa kontekstā}

Operatīvās darbības uzdevums ir iegūt informāciju par personu noziedzīgajām aktivitātēm un pārtraukt tās. Tātad jāiegūst informācija par personu noziedzīgās darbības aktu, kurš OE ietvaros jāfiksē. Tas, kā personu sauc, nav svarīgi. Svarīgi, lai operatīvās darbības dokumentācijā tiek atklāti procesa attīstības posmi, parādītas cēloṇsakarības kontakta nodibināšana un personas piedalǐšanās nozieguma izdarǐšanā. Operatīvās darbības materiāliem jāatklāj, kā OE veicējs ar personu nodibina kontaktu. Kontakta nodibināšanas laikā jāiegūst materiāls (DNS, pirkstu nospiedumi, foto, balss ieraksts), kas turpmākās izmeklēšanas gaitā l̦aus šo konkrēto personu identificēt kā personu, kura OE gaitā izšķiras veikt noziegumu. Personas darbïbas jāfiksē ar audio un / vai video tehniskajiem lïdzeklịiem, kā tas paredzēts ODL 15. panta trešajā dạ̦ā. Kontakta nodibināšanas un noziedzīgās rīcības dokumentēšana ir ārkārtīgi svarīga, lai pierādītu, ka OE uzsākšanas laikā jeb eksperimenta pirmajā posmā piedalās tā pati persona, kas OE noslēguma posmā izšḳiras veikt noziedzīgas darbības. Operatīvās darbības gaitā jāveic operatīvā personas identifikācija, līdzīgi kā operatīvās darbības procesā tiek veikta operatīvā noziedzīga nodarījuma kvalifikācija, kas konkrētās operatīvās lietas ietvaros tiek izmeklēta. Vēlāk, kad personas aizturēšana jau būs notikusi, operatīvās darbības gaitā iegūtā informācija (materiāls), kas saistīta ar personas identifikāciju (pirkstu nospiedumi, DNS u. c.), būs jāpārbauda kriminālprocesa noteiktajā kārtībā, kā tas notiek ar jebkuru operatīvās darbības rezultātā iegūtas informācijas nostiprināšanu pierādỉjuma statusā (Kriminālprocesa likuma 127. panta trešā daḷa). Šajā gadījumā informācija kriminālprocesā tiktu pārbaudīta attiecīgas ekspertīzes ietvaros vai uzrādot personu atpazíšanai.

Kontekstā ar minētajiem secinājumiem jānorāda arī uz kriminālistikas literatūras atziņām, ka operatīvā personas konstatācija (identifikācija) notiek tad, kad policijas darbinieks, zemessargs vai kāds cits cilvēks atpazīst meklējamo pēc publicētas fotogrāfijas, subjektīvā vai sintētiskā portreta vai arī pēc ārienes pazìmju apraksta operatīvajā apkārtrakstā vai meklēšanas plakātā. Šādai atpazišanai gan nav pierādījuma nozīmes kriminālprocesā, taču tā var būt pamats citām procesuālajām (un operatīvajām - aut. piebilde) darbībām, lai identificētu meklējamā personību vai identificētu viṇu kā nozieguma izdarītāju [13, 103, 124]. Operatīvās darbības ietvaros jābūt iespējai veikt OE, lai fiksētu personas noziedzīgo rīcību, kaut arī interesējošā persona tobrīd ir identificēta pēc, piemēram, personas fiziskajām pazīmēm, personas fotogrāfijas, video vai balss ekspertīzes 
ietvaros. Tāpat jābūt iespējai veikt $\mathrm{OE}$ ar neidentificētu personu, taču personai, pret kuru vērsts operatīvais pasākums, jāatbilst noteiktiem identifikācijas kritērijiem (saistība ar konkrētu automobili, tālruṇa numuru, IMEI / IMSI kodu, interneta vietnes konta lietotājvārdu, IP adresi), respektīivi, jāizslēdz gadījumi, ka pasākums tiek veikts attiecībā pret nekonkrētu personu loku. Operatīvās darbības procesā tiek veikta operatīvā personas noziedzīgās rīcības kvalifikācija, tādēl nav tik būtiski, vai šo personu var identificēt pēc identifikācijas datiem. Šos datus var noskaidrot (ja tas ir iespējams) citā operatīvās darbības vai pirmstiesas izmeklēšanas posmā. Operatīvās darbības gaitā jārada pierādījumu un informācijas avoti, kurus var izmantot pierādīšanas gaitā kriminālprocesā. Arī operatīvā ceḷā iegūtos indivīda pirkstu nospiedumus OE sākotnējā un beigu posmā (kontakta nodibināšana - personas izdarìts noziegums) iespējams vēlāk nostiprināt kriminālprocesuālā ceḷā, piemēram, veicot pirkstu nospiedumu daktiloskopisko ekspertīizi.

Tāpat persona, kura OE uzsākšanas brīdī nebija identificēta, pēc OE tiek identificēta, un tās dalība nozieguma izdarī̌̌anā vai nu apstiprinās, vai neapstiprinās. Nedrīkst aizmirst, ka operatīvās darbības ietvaros notiek nemitīga informācijas pārbaude. Atsevišķās situācijās informācijas pārbaude var būt iespējama tikai OE ietvaros, tādēḷ nedrīkst šo darbību liegt tāpēc, ka tā brīža faktiskie apstākḷi liedz personu identificēt pēc vārda, uzvārda, personas koda vai ar citiem iepriekš minētajiem indivīda identifikācijas veidiem, taču zināmie apstākḷi un noskaidrotie fakti liecina par kādas konkrētas personas noziedzīgajām aktivitātēm.

\section{Operatīvajam eksperimentam analogu pasākumu tiesiskais regulējums kaimiņvalstīs}

Lietuvas Republikā Latvijas operatīvajam eksperimentam analogs pasākums noteikts Kriminālās izlūkošanas likuma 2. panta astotā punkta 6. apakšpunktā (Noziedzīgas rīcības imitācija, Simulation of a criminal offense), kura detalizētāks skaidrojums dots 2. panta 14. punktā. Saskañā ar Kriminālās izlūkošanas likuma 2. panta 14. punktu noziedzīgas rīcības imitācija ir kriminālās izlūkošanas datu vākšanas metode, kas formāli ietver kriminālpārkāpuma vai cita likumpārkāpuma izdarī̌̌anas pazīmes un tiek lietota ar nolūku aizsargāt cilvēka tiesības un brīvību, ỉpašumu, sabiedrības drošību un valsti [7]. Apskatot šā panta daḷas, var secināt, ka regulējumā nav noteikts, ka nepieciešams zināt identitātes datus personai, pret kuru pasākums tiek piemērots. Lietuvas normatīvā regulējuma normās nav ietverts strikts nosacījums, ka pasākums jārealizē tikai pret tām personām, kurām zināms vārds, uzvārds un personas kods. Konsultējoties ar Lietuvas operatīvās darbības tiesību speciālistu un ilggadējo praktiḳi Dr. iur. Vladu Tumalaviču (Vladas Tumalavičius), tika noskaidrots, ka Lietuvas tiesībsargājošās iestādes ir tiesīgas veikt operatīvo darbību, kas izpaužas noziedzịgas rīcības imitācijā, arī pret personām, kuru vārds, uzvārds un personas kods nav zināms. 
Var secināt, ka Lietuvas tiesiskajā regulējumā nav ietverts nosacijums, kas aizliegtu veikt operatīvajam eksperimentam analogu noziedzīgas rīcības imitācijas pasākumu pret personām, kuru identifikācijas dati nav zināmi. Likums arī neparedz personai noteikt sevišḳu statusu, lai pret to varētu veikt attiecīgo pasākumu.

Igaunijas Republikā Latvijas operatīvajam eksperimentam analogs pasākums noteikts Kriminālprocesa kodeksa $126 .{ }^{8}$ pantā (Noziedzīgas rīcības iestudēšana, Staging of criminal offence). Jēdziena staging nozīme ir "situācijas iestudēšana", "noteiktu apstākḷu radīšana uz konkrētu brīdi" [19]. 126. ${ }^{8}$ panta pirmajā dal̦ā noteikts, ka pasākumu aț̣auts veikt, nepārkāpjot $126 .{ }^{1}$ panta trešajā punktā noteiktos ierobežojumus. $126 .{ }^{1}$ panta trešajā punktā noteikts, ka iestāžu veiktie pasākumi nedrīkst apdraudēt cilvēka dzīvību vai veselību, nodarìt nepamatotu kaitējumu personas īpašumam vai apkārtējai videi, kā arī veiktie pasākumi nedrīkst radīt nepamatotu personas tiesību pārkāpumu. Citi ierobežojumi vai nosacījumi, izṇemot pasākuma saskaṇošanu ar tiesu, $126 .{ }^{8}$ pantā nav minēti [2]. Analizēto tiesisko normu saturā nav saskatāmi nosacỉjumi, ka šāda veida pasākums jāveic pret personu ar seviškłu procesuālu statusu (ODL - izstrādē esoša persona) vai nosacỉjumu, ka personas identifikācijas datiem jābūt noskaidrotiem.

Krievijas Federācijā (turpmāk - KF) Latvijas operatīvajam eksperimentam analogs pasākums (kontrolpirkums, test purchase un operatīvais eksperiments, operational experiment / operational-search experiment) noteikts Operatīvo meklēšanas pasākumu likuma 8. pantā. Saskaṇā ar šajā pantā noteikto aizliegto vai ierobežotas aprites vielu, priekšmetu un produktu kontrolpirkums, tāpat kā operatīvais eksperiments, ko veic operatīvos meklēšanas pasākumus veicošās amatpersonas vai personas, kuras sniedz tām atbalstu, tiek veikts, pamatojoties uz lēmumu, ko apstiprinājis iestādes vadītājs. Operatīvais eksperiments veicams tikai gadījumos, lai atklātu, novērstu un apkarotu smagus noziegumus, kā arī atklātu un identificētu personas, kuras gatavojas, veic vai jau ir izdarījušas noziegumus [3]. Analizējot šo normu saturu, var konstatēt, ka KF tiesiskajā regulējumā nav ietverts nosacījums par šã veida pasākumu veikšanu tikai pret personu ar īpašu procesuālu statusu vai nosacījums, ka personas identifikācijas datiem jābūt noskaidrotiem.

\section{Operatīvā eksperimenta mērḳu analīze kopskatā ar pētījuma problēmjautājumiem}

Raksta turpinājumā jāatgriežas pie nozieguma veidiem, kuri aprakstīti pirmajā modelētajā situācijā, t. i., noziegumiem, kas veikti, izmantojot interneta vidi. Šo noziegumu izdarīšanas mehānisms praksē šobrīd ir loti bieži sastopams, tādēl svarīgi noskaidrot, kā amatpersonām jārīkojas šādu noziegumu izmeklēšanā. Piemērā tika secināts, ka šādu personu identificēšana nav iespējama, jo ar tām nenotiek tieša redzes komunikācija. Lìdz persona nav satikta vai fiksēta videozvana vai interneta sarunas laikā, viṇu identificēt pēc vizuālā izskata vai balss unikālajām īpašībām, attiecīgi veicot portreta (fotoattēla / video) vai balss fonoskopisko ekspertīzi, nav iespējams. Persona, kura izdara noziegumu, 
visticamāk, nevēēēsies komunicēt videozvana vai interneta savienojuma sarunas ietvaros, bet drīzāk aprobežos savas aktivitātes ar saraksti, kas faktiski neḷauj to identificēt (ja izmanto iepriekš uzskaitītos IP adreses slēpšanas paṇēmienus). Tātad praksē rodas situācijas, kurās par noziegumu veicošo personu nav zināms nekas vairāk kā tikai tās kontaktinformācija internetā, piemēram, lietotājvārds interneta vietnē. Kā amatpersonai organizēt OE, ja ir šādi apstākḷi?

Šì jautājuma kontekstā jānorāda uz ODL noteiktajiem operatīvā eksperimenta mērḳiem, proti, "noskaidrot interesējošās personas" un "noskaidrot interesējošās lietas", un amatpersonu darbības aktiem operatīvo eksperimentu veidos, t. i., "radìt labvēlīgu situāciju" (ODL 15. panta otrās daḷas 3. punkts) un "fiksēt" (ODL 15. panta trešā daḷa). [8]

Tātad ir iespējams veikt eksperimentu, lai radītu apstākḷus, kuros parādās iespēja noskaidrot personas un lietas, un tas izdarāms operatīvā eksperimenta veida ietvaros, kura darbības akts izpaužas kā "labvēlīgu apstākḷu radīšana" jeb operatīvais eksperiments, kurš noteikts ODL 15. panta otrās daḷas 3. punktā [8]. Izpildot šo eksperimenta veidu, interesējošā persona var tikt izvilināta ārpus interneta vides aizsega, tādējādi rodot iespēju to fiksēt un vēlāk identificēt konkrētas ekspertīzes ietvaros vai noskaidrojot personas identifikācijas datus. ODL 15. panta trešajā dạ̣ā noteiktā operatīvā eksperimenta veida darbības akts ir "fiksēt". Tātad gadījumā, ja amatpersonas mērḳis nav "fiksēt" personas noziedzīgo rīcību, bet "radīt labvēlīgus apstākḷus", lai veicinātu personas noskaidrošanu un pārliecinātos par, piemēram, nelegāla, funkcionējoša ieroča esamību, minētie mērḳi jāsasniedz operatīvā eksperimenta veidā, kas noteikts ODL 15. panta otrās daḷas 3. punktā, un šim eksperimenta veidam likumā nav noteikts nosacījums, ka pasākums veicams pret personām, attiecībā uz kurām uzsākta operatīvā izstrāde. Pasākuma ietvaros tiktu noskaidrota personas identitāte (persona būtu identificējama) un tiktu gūts apstiprinājums, piemēram, nelegālu ieroču esamībai. Šāds informācijas apjoms būtu pamatojums OE veikšanai ar mērḳi fiksēt personas noziedzīgās aktivitātes. Taču jāatzīst, ka minētā operatīvā eksperimenta veida izpildes laikā jau notiktu sarunas par, piemēram, OE veicējam uzrādītā ieroča tehniskajiem datiem, iespējams, tiktu veikti izmēgeinājuma šāvieni un notiktu sarunas par iegādes cenu, ieroču izcelsmi, piegādi, norēḳināšanos u. tml. jautājumiem, tādēl var secināt, ka arī šì eksperimenta veida gaitā notiek darbības, kuras nepieciešams fiksēt, jo pirmstiesas izmeklēšanas procesā šìm ziṇām būs nozīme, lai personai inkriminētu noziedzīgās darbības un secinātu, vai notikusi provokācija (vai ievērota pasīvas izmeklēšanas maniere). Tātad, atklājot komplicētus noziegumus, amatpersonas operatīvā eksperimenta veidu ietvaros vienlaikus veiks divus darbības aktus "radīs labvēlīgu situāciju" un "fiksēs" personu noziedzīgās aktivitātes. Plānojot un veicot pasākumus, nebūs zināma interesējošās personas identitāte (nedz vārds, uzvārds, nedz vizuālās īpašības, nedz biolog̣iskais materiāls ar unikālajām īpašỉbām, piemēram, DNS), bet - tas ir svarīgi - tā tiks noskaidrota pasākuma izpildes gaitā vai pēc tā, veicot citus pasākumus. 
Līdzīga situācija atklājas narkotisko vielu apkarošanas darbā. Izveidojot labvēlīgu situāciju, lai personu izvilinātu ārpus interneta vides, piemēram, norunājot tikšanos vai radot apstākḷus, lai persona noteiktā laikā būtu kādā noteiktā vietā un līdz ar to būtu identificējama, tiks îstenots amatpersonu darbības akts "radìt labvēlīgu situāciju", kas neparedz nosacījumu, ka personai jābūt iekḷautai operatīvajā izstrādē (jābūt identificētai). Minētajā situācijā (piemēram, norunāta tikšanās) var nākties runāt par narkotisko vielu apjomu, cenu, piegādes un samaksas kārtību un citiem specifiskiem noziedzīgās rīcības mehānisma elementiem, kuriem ir pierādīšanas nozīme pirmstiesas izmeklēšanas procesā, un sarunas saturs var atklāt eksperimenta veicēja provokatīvu aktivitāti, kā arī izveidotās "labvēlīgās situācijas" laikā var rasties nepieciešamība (jo to pieprasa šāda nozieguma izdarīšanas specifiskā daba) nopirkt narkotiskās vielas, un šāda aktivitāte ietver personas noziedzīgu rīcību, kas jāfiksē (ODL 15. panta trešās daḷas izpratnē). Atkārtoti var secināt, ka traucējošs ir ODL 15. panta trešās daḷas nosacījums, ka pasākums veicams pret personām, attiecībā uz kurām tiek veikta operatīvā izstrāde, jeb persona ir identificēta pēc vārda, uzvārda un personas koda. Šis nosacỉjums nevajadzīgi ierobežo iestāžu tiesiskās darbỉbas cinnā pret noziedzību. Faktiski tas nepiel̦auj amatpersonu tiesisku rīcību, kuras laikā šis nosacījums tiktu izpildìts, t. i., persona tiktu identificēta.

Praktiskā darba situāciju modelēšanas un analīzes rezultāti l̦auj secināt, ka neidentificējamu personu noskaidrošana iespējama, secīgi veicot divus operatīvā eksperimenta veidus jeb divus darbības aktus: "radīt labvēlīgu situāciju" un "fiksēt". Šāds divu atškirīigu operatīvo eksperimentu tandēms īstenotos līdzīgi kā operatīvā sarunu noklausīšanās un operatīvā publiski nepieejamas vietas videonovērošanas veikšana (ODL 17. pants), kad tā tiek realizēta vienlaikus ar operatīvo iekḷuššanu (ODL 14. pants). Bez operatīvās iekḷū̌̌anas nav iespējams interesējošajās telpās uzstādīt audio un / vai video fiksējošu aparatūru. Arī aprakstītajiem eksperimenta veidiem ir līdzīgas izpausmes īpašỉbas. ODL 15. panta otrās dal̦as 3. punkta izpratnē operatīvā eksperimenta būtỉba ir citu operatīvo pasākumu veicināšana, tāpat kā tas izpaužas operatīvās iekḷūšanas laikā.

Jākonstatē, ka personas, kuras slēpjas interneta vidē, izmantojot tehnologiskās iespējas, var atmaskot, organizējot darbu pēc šeit aprakstītā model̦a, taču praktiski to nevar realizèt ODL 15. pantā noteiktā nosacījuma nepareizas interpretācijas dēḷ.

\section{Secinājumi un priekšlikumi}

Pētījuma gaitā tika secināts, ka aplama ir operatīvajā darbībā ieviestā prakse uzskatīt, ka konkrēta persona ir tā persona, kurai zināms vārds, uzvārds un personas kods, un šāds uzskats vairākās situācijās traucē operatīvās darbības subjektiem sekmīgi izpildīt to kompetences mērḳus un uzdevumus, kā arī tas ir pretrunā ar operatīvās darbības būtỉbu un mērḳi.

Trīs Latvijas kaimiņvalstu - Lietuvas, Igaunijas un Krievijas Federācijas - analogu pasākumu tiesiskā regulējuma analīzes rezultāti liecina, ka šo valstu likumos nav ietverti 
nosacỉjumi, kas aizliegtu pasākuma veikšanu pret personām, kam nav sevišșka procesuālā statusa (Latvijā normatĩvajā regulējumā šis statuss ir noteikts - izstrādē esoša persona), vai aizliegtu veikt pasākumu pret personu, kuras identifikācijas dati nav noskaidroti.

Jāuzsver, ka no pētijuma satura izriet būtisks secinājums: likumā lietotais jēdziens "konkrēta persona" neliedz uzsākt operatīvo izstrādi pret konkrētām personām, kuras sabiedrībā izšḳiramas pēc, piemēram, to lietotā tālruṇa numura vai lietotājvārda interneta vietnē un ar to starpniecību paustās informācijas satura, kas norāda uz indivīda, kurš operatīvās darbības gaitā tiktu identificēts, noziedzīgo aktivitāti.

\section{Priekšlikumi:}

1. Izslēgt ODL 15. panta pirmajā un trešajā dal̦ā ietverto nosacījumu "attiecībā uz kurām tiek veikta operatīvā izstrāde" un ietvert norādi (nosacījumu) par to, kādai informācijai jābūt iegūtai, lai varētu veikt $\mathrm{OE}$, - "dod pietiekamu pamatu turēt aizdomās par noziedzīga nodarījuma gatavošanu vai izdarīšanu" - un ietvert norādi, ka pasākums jāveic pret konkrētām personām (sk. piedāvāto normas jauno redakciju).

2. Normatīvajā regulējumā (iestāžu iekšējās instrukcijās) un praksē paredzēt iespēju operatīvās darbỉbas procesa ietvaros fiksēt personas identifikācijai nepieciešamo materiālu (personas DNS saturošo biologíisko materiālu, pirkstu nospiedumus, personas fotogrāfiju (video), balss ierakstu) un paredzēt konkrētās personas identifikāciju ar šādiem identifikācijas paṇēmieniem: DNS, daktiloskopisko, habitolog̣isko (portreta) un fonoskopisko ekspertīzi, savukārt vēlāk, jau uzsākta kriminālprocesa ietvaros, - uzrādot personu atpazī̌anai. Persona, kura fiksēta un ir identificējama ar minētajiem identifikācijas paṇēmieniem, uzskatāma par "konkrētu personu" (sk. piedāvāto normas jauno redakciju).

Šāda iespēja jāparedz gadījumos, kad objektīvie apstākḷi liedz personu identificēt ierastajā ceḷā. Pasākuma lēmums amatpersonai jāsaskaṇo ar pasākumu akceptējošo amatpersonu - prokuroru un / vai Augstākās tiesas tiesnesi, kuri arī vērtētu, vai pastāv objektĩvi apstākḷi, kas liedz personu identificēt ierastajā veidā.

Balstoties uz pētījuma secinājumiem un priekšlikumiem, var piedāvāt ODL 15. panta (Operatīvais eksperiments) pirmo un trešo dalı izteikt jaunā redakcijā:

1) Operatīvais eksperiments ir operatīvās darbïbas subjektu amatpersonu darbība, kuras mērḳis ir radīt noteiktus apstākḷus (situāciju), lai noskaidrotu interesējošās personas un lietas vai arī noteiktu šajos apstākḷos personu rīcību vai lietu kustỉbu un noskaidrotu šo personu rīcỉbas motivāciju (subjektīvo pusi).

3) Operatīvais eksperiments, kura mērḳis ir fiksēt, kā noziedzīgu vai citādu prettiesisku rīcību izraisošã situācijā rīkojas konkrētas personas, par kurām iegūtā informācija dod pietiekamu pamatu turēt šīs personas aizdomās par noziedzīga nodarījuma gatavošanu vai izdarī̌̌anu, izdarāms, pamatojoties uz operatīvās darbỉbas subjekta amatpersonas lēmumu, ko akceptējis prokurors. 


\section{Operative Experiment Problematics}

\section{Abstract}

Operational activities law of the Republic of Latvia section 15 paragraph three determines specific investigative experiment type (also called as operative experiment), the purpose of which is to record how persons in relation to whom the investigatory process is being conducted, act in a situation eliciting a criminal or other illegal act. To perform this measure, a person against whom the measure is targeted has to be included in specific operative investigatory status, and to add a person to that status, investigation unit has to know the exact person's identity data (name, surname and national identification code).

The article is about the requirement that investigatory experiment can be performed only against a person whose identification data are known and how that rule limits the possibilities to use the measure in fighting certain types of crime.

Keywords: operative activities, operative experiment, entrapment, provocation, incitement, particular person (individual), identified person (individual).

\section{Avoti un literatūra}

\section{Tiesību akti}

1. Administratīvā procesa likums: Latvijas Republikas likums. Latvijas Vēstnesis. 164(2551), 14.11.2001.

2. Code of Criminal procedure (Igaunijas Republikas Kriminālprocesa kodekss). Riigi Teataja. 2003. Iegūts no: http://ej.uz/971b [sk. 20.02.2018.].

3. Federal law No. 144-FZ on Operational search acivities (Krievijas Federācijas Operatīvo meklēšanas pasākumu likums). Imolin. 2006. Iegūts no: http://ej.uz/ktx7 [sk. 20.02.2018.].

4. Ieroču un speciālo līdzekḷu aprites likums: Latvijas Republikas likums. Latvijas Vēstnesis. 183(4375), 17.11.2010.

5. Kriminālprocesa likums: Latvijas Republikas likums. Latvijas Vēstnesis. 74(3232), 11.05.2005.

6. Law on operational activities: Republic of Lithuania (Lietuvas Republikas Operatīvās darbības likums). Legislationline. 2002. Iegūts no: http://ej.uz/z191 [sk. 20.02.2018.].

7. Lietuvos Respublikos kriminalinės žvalgybos ịstatymas. Lietuvos Respublikos Seimas. Valstybès žinios. 122(6093), 10.20.2012. Iegūts no: https://www.e-tar.lt/portal/lt/legalAct/ TAR.3B8E4F16C815 [sk. 20.02.2018.].

8. Operatīvās darbïbas likums: Latvijas Republikas likums. Latvijas Vēstnesis. 131, 30.12.1993.

\section{Tiesu prakse}

9. Eiropas Cilvēktiesību tiesas 2007. gada 26. janvāra spriedums lietā "Khudobin pret Krieviju", iesniegums Nr. 59696/00. Council of Europe. Iegūts no: http://ej.uz/tpyc [sk. 12.05.2018.].

\section{Literatūra}

10. Canadian police need to rethink the Mr. Big police method. 2018. The Tyee [News, culture, solutions]. Iegūts no: http://ejuz.lv/jhp [sk. 12.05.2018.]. 
11. Egan, M. 2018. What is dark web? Tech advisor. Iegūts no: http://ej.uz/mouo [sk. 20.02.2018.]. 12. Greenberg, A. 2014. What is the dark web? Wired. Iegüts no: https://www.wired.com/2014/11/ hacker-lexicon-whats-dark-web/ [sk. 20.02.2018.].

13. Kavalieris, A. 2003. Kriminālistika. Rīga: Latvijas Policijas akadēmija.

14. Kriminālistikas un operatīvās darbības latviešu, angḷu, vācu un krievu terminoloğijas skaidrojošā vārdnīca. 2007. Aut. kol. Dr. habil. iur. A. Kavaliera vad. Rīga: Latvijas Policijas akadēmija.

15. Latvijas Zinātnes padomes lēmums Nr. 2-3-1 par jauno zinātnes apakšnozaru izveidošanu juridisko zinātṇu nozarē. Zinātṇu nozaru un apakšnozaru saraksts. 2018. Latvijas Zinātnes padome. Iegūts no: http://ej.uz/g6qf [sk. 20.02.2018.].

16. Mr. Big (police procedure). Wikipedia. Iegūts no: http://ejuz.lv/jho [sk. 12.05.2018.].

17. Orfox: A Tor browzer for android. Guardian Project. Iegūts no: https://guardianproject.info/ apps/orfox/ [sk. 20.02.2018.].

18. Suvorovs, V. 2016. Spiegošanas pamati. Kà strādāja visvarenākā un visnoslēgtākā 20. gadsimta izlūkošanas organizācija. Rīga: Dienas Grāmata.

19. Terminu skaidrojošā vārdnīca. Dictionary.com Iegūts no: http://www.dictionary.com/browse/ staging [sk. 20.02.2018.].

20. Vinogradov, D. 2015. 1 in 3 Syrian refugees have fake ID, German authorities admi. RT. Iegūts no: http://ej.uz/dht1 [sk. 20.02.2018.]. 